\title{
Proteomic Analysis Reveals Grb2 as a Key Regulator of Periodic Mechanical Stress Transduction in Chondrocytes
}

\author{
Shun Xu Zeng Li Zhen Wang Chenjun Zhai Wenwei Liang Chunhui Zhu \\ Weimin Fan
}

The First Affiliated Hospital of Nanjing Medical University, Department of Orthopedics, Nanjing, China

\section{Key Words}

Periodic mechanical stress $•$ Proteomic analysis $\bullet$ Chondrocyte $\bullet$ Grb2

\begin{abstract}
Background/Aims: Periodic mechanical stress could significantly promote chondrocyte proliferation and matrix synthesis. However, the mechanisms underlying the ability of chondrocyte detecting and responding to periodic mechanical stimuli have not been well delineated. Methods: Quantitative proteomic analysis was performed to construct the differently expressed proteome profiles of chondrocyte under pressure. Then a combination of Western blot, quantitative real-time PCR, lentiviral vector and histological methods were used to confirm the proteomic results and investigate the mechanoseing mechanism. Results: Growth factor receptor-bound protein 2 (Grb2), a component of integrin adhesome, was found a 1.49-fold increase in dynamic stress group. This process was mediated through integrin $\beta 1$, leading to increased phosphorylation of focal adhesion kinase (FAK) and extracellular signalregulated kinase 1/2 (ERK1/2) respectively and then produce the corresponding biological effects. Conclusion: This was the first time to demonstrate Grb2 has such an important role in periodic mechanotransduction, and the proteomic data could facilitate the further investigation of chondrocytes mechanosensing.

\section{Introduction}

Periodic mechanical stress can improve the quality of tissue-engineered cartilage by promoting chondrocytes proliferation and matrix synthesis [1-3]. Numerous studies have recently attempted to elaborate the mechanisms underlying chondrocytes mechanosensing and signaling in response to periodic mechanical stimuli. Chaturvedi et al. demonstrated an association between ERK1/2 and cyclic mechanical strain-induced pulmonary epithelial cell proliferation [4]. Kock et al. confirmed that integrins acted as mechanotransducers in

S. Xu and Z. Li contributed equally to this work.

Weimin Fan

KARGER 


\section{Cellular Physiology Cell Physiol Biochem 2017;44:1509-1525

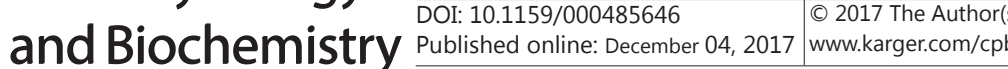 \\ Xu et al.: Grb2 Mediate Mechanotranduction in Chondrocytes}

dynamically compressed tissue-engineered cartilage constructs [5]. He and co-workers found periodic mechanical stress activated PKC $\delta$-dependent EGFR mitogenic signaling PI3K-Akt and ERK1/2[6]. In addition, we previously showed that periodic mechanical stress accelerated chondrocytes proliferation and matrix synthesis via mitogenic signaling pathways and CaMKII-mediated Pyk2 Signaling [7-10]. However, these previous studies only discussed several proteins or an individual signal cascade in the transduction of mechanical stimuli. This lack of systematic analysises prevented an insight on the molecular mechanisms underlying chondrocyte sensing and responding to periodic mechanical stress.

Bougault et al. once applied genomic analysis to investigate the impact of dynamic compression on genome-wide gene expression in chondrocytes. Microarray analysis in chondrocytes after $30 \mathrm{~min}$ of dynamic compression revealed that 325 genes expression were changed, including those related to the mitogen-activated protein kinase (MAPK) and transforming growth factor- $\beta$ pathways [11]. This study may help appreciation of chondrocytes responding to mechanical forces based on analysis of the overall genome, however, proteins are executors of numerous biological functions, and many factors affect the process whereby gene expression produces proteins, leading to potential inconsistencies in gene and corresponding protein expression [12]. Although the genomic method has improved our understanding of the mechanisms underlying mechanotransduction in chondrocytes, further clarification is still needed.

Proteomic processes have recently been utilized successfully to study articular cartilage, including investigation of differential expression profiling in osteoarthritis chondrocytes [13], the global effects of compressive mechanical stress on rat mandibular cartilage [14], and proteomic analysis of engineered articular cartilage [15]. This proteomic method can provide quantitative information of most proteins in samples, and thus help us to reveal the molecular mechanisms underlying biological phenomena. However, the protein expression profiling of chondrocytes under periodic mechanical stress has not yet been reported. Isobaric tags for relative and absolute quantitation (iTRAQ) provides one of the most comprehensive used quantitative proteomic analysis technique, with the advantages of high throughput and high stability, independent of the sample properties [16]. This technology uses amine-specific isobaric tags to compare the intensities of reporter ions of labeled peptides, and thus infer quantitative values for the corresponding proteins [17]. To facilitate the investigation of periodic mechanical stress-induced chondrocyte proliferation and matrix synthesis, we applied iTRAQ labeling coupled with two-dimensional (2D) LC/ MS/MS proteomic technology to allow the quantitative evaluation of proteins expression in chondrocytes subjected to cyclic mechanical stress.

\section{Materials and Methods}

\section{Construction of a periodic mechanical stress field}

A periodic stress field with adjustable stress intensity and frequency was constructed to encompass the perfusion culture system by connecting a reciprocating intensifier pump to the air-tight cell culture device (Taixing Experimental Instrument Factory, Taixing, Jiangsu, China) through a barrier-type pressure transducer (Tianjin Plastics Research Institute, Tianjin, China), as described previously [7]. We previously found that rabbit chondrocytes subjected to stress varying from $0-200 \mathrm{kPa}$ at $0.1 \mathrm{~Hz}$ yielded the best quality tissue-engineered cartilage [40]. We accordingly used a pressure range of 0-200 $\mathrm{kPa}$ and $0.1 \mathrm{~Hz}$ frequency in the current study.

\section{Cell culture}

Chondrocytes were harvested as described by Séguin and Bernier. Briefly [45], cartilage derived from the limb joints of 2-week-old SD rats was sliced into $1-\mathrm{mm}^{3}$ pieces under sterile conditions. The pieces were digested with $0.25 \%$ trypsin at $37^{\circ} \mathrm{C}$ for $0.5 \mathrm{~h}$, followed by digestion with $0.2 \%$ collagenase II (Sigma, St Louis, MO, USA) at $37^{\circ} \mathrm{C}$ for $4 \mathrm{~h}$. Cells were harvested by filtering with a 200 -mesh filter and cultured in DMEM-F12 medium supplemented with $10 \% \mathrm{FBS}$ in an incubator at $37^{\circ} \mathrm{C}$ with $5 \% \mathrm{CO}_{2}$. The cell population 


\section{Cellular Physiology Cell Physiol Biochem 2017;44:1509-1525 and Biochemistry Published online: December 04, 2017 www.karger.com/cpb}

Xu et al.: Grb2 Mediate Mechanotranduction in Chondrocytes

was purified by repeated adherence, and cell morphology was examined under an inverted phase-contrast microscope following staining for collagen type II, according to the conventional ABC method. Secondgeneration cells were seeded onto sterile glass coverslips (25 $\mathrm{mm} \times 25 \mathrm{~mm})$ coated with type II collagen at a density of $10^{5}$ cells. The chondrocytes were then cultured for 3 days under no-pressure conditions (group A) or under periodic mechanical stress (group B) for $8 \mathrm{~h} /$ day, lasting 3 days, prior to reverse transcriptionpolymerase chain reaction (RT-PCR) analysis for aggrecan and type II collagen gene expression, CCK- 8 assay, direct cell counting, and proteomic analysis. Regarding to inhibite the mechanical maturation of focal adhesions, Blebbistatin (Sigma, St Louis, MO, USA), which was prepared as a 5- $\mu$ M solution in DMSO, was used to pretreat the chondrocytes. All experiments involving animals were performed according to the guidelines of the National Institutes of Health and Nanjing Medical University, and all protocols were approved by the Institutional Animal Care and Use Committee of Nanjing Medical University (Nanjing, China).

\section{Protein preparation and digestion}

Total cell protein extract was lysed on ice in SDT buffer (4\% sodium dodecyl sulfate (SDS), $1 \mathrm{mM}$ dithiothreitol (DTT), $150 \mathrm{mM}$ Tris-HCl pH 8.0) and subsequently centrifuged for $15 \mathrm{~min}$ at 14, $000 \times \mathrm{g}$. The total protein concentration was determined by BCA protein assay. Protein digestion was performed according to the universal sample preparation method described by Wisniewski et al [46].. Briefly, $200 \mu \mathrm{g}$ total protein from each sample was diluted in $30 \mu \mathrm{L}$ 4\% SDS, $100 \mathrm{mM}$ Tris-HCl pH 8.0, and $100 \mathrm{mM}$ DTT, and heated at $95^{\circ} \mathrm{C}$ for $5 \mathrm{~min}$. Each sample was cooled to room temperature and loaded onto a $10-\mathrm{kDa}$ ultrafiltration filter. We added $200 \mu \mathrm{L}$ UA buffer ( $8 \mathrm{M}$ urea, $150 \mathrm{mM}$ Tris- $\mathrm{HCl}, \mathrm{pH} 8.0$ ) to the filter, followed by centrifugation at $14,000 \times \mathrm{g}$ at $20^{\circ} \mathrm{C}$ for $15 \mathrm{~min}$. Iodoacetamide solution (100 $\mu \mathrm{L} 50 \mathrm{mM}$ in UA buffer) was then added to block reduced cysteines. The samples were oscillated at $600 \times \mathrm{g}$ for $1 \mathrm{~min}$ and incubated for $30 \mathrm{~min}$ in darkness. The filters were then centrifuged at $14,000 \times \mathrm{g}$ at $20^{\circ} \mathrm{C}$ for $10 \mathrm{~min}$ and washed with $100 \mu \mathrm{L}$ UA buffer at $14,000 \times \mathrm{g}$ for $10 \mathrm{~min}$. This step was repeated twice, followed by the addition of $100 \mu \mathrm{L}$ dissolution buffer (AB Sciex, Framingham, MA, USA) to the filter and centrifugation at 14, $000 \times \mathrm{g}$ at $20^{\circ} \mathrm{C}$ for $10 \mathrm{~min}$, repeated twice. Finally, $40 \mu \mathrm{L}$ of trypsin (Promega, Madison, WI, USA) buffer (5 $\mu \mathrm{g}$ trypsin in $40 \mu \mathrm{L}$ dissolution buffer) was added, and the samples were digested overnight at $37^{\circ} \mathrm{C}$. Each filter unit was transferred to a new tube and centrifuged at $14,000 \times \mathrm{g}$ at $20^{\circ} \mathrm{C}$ for $10 \mathrm{~min}$. The resulting peptide concentrations were estimated by UV light spectral density at optical density $280 \mathrm{~nm}$.

\section{iTRAQ labeling}

The resulting peptide mixture was labeled using 8-plex iTRAQ reagent (AB SCIEX) according to the manufacturer's instructions. Two samples from the no-pressure group (A1, A2) were labeled with mass 113 and 114 isobaric iTRAQ tags, while three samples from the pressure group (B1, B2, B3) were labeled with mass 115, 116 and 117 isobaric iTRAQ tags. The labeling solution was incubated at room temperature for $2 \mathrm{~h}$ before further analysis.

\section{Strong cationic-exchange (SCX) chromatography}

iTRAQ-labeled peptides were fractionated by SCX chromatography using the AKTA Purifier system (GE Healthcare). The dried peptide mixture was redissolved and acidified with 2 ml Buffer A (10 mM KH $\mathrm{PO}_{4}$ in $25 \%$ ACN, pH 2.7) and loaded onto a Polysulfoethyl column $(4.6 \times 100 \mathrm{~mm}, 5 \mu \mathrm{m}, 200 \AA$, PolyLC Inc., Columbia, MD, USA). The peptides were eluted at a flow rate of $1 \mathrm{~mL} / \mathrm{min}$ with a gradient of $0 \%-10 \%$ Buffer B (500 mM KCl and $10 \mathrm{mM} \mathrm{KH}_{2} \mathrm{PO}_{4}$ in 25\% ACN, pH 2.7) for $10 \mathrm{~min}, 10 \%-20 \%$ Buffer B for $10 \mathrm{~min}$, $20 \%-45 \%$ Buffer B for $5 \mathrm{~min}$, and 45\%-100\% Buffer B for $5 \mathrm{~min}$. The elution was monitored by absorbance at $214 \mathrm{~nm}$, and fractions were collected every $1 \mathrm{~min}$. The collected samples were finally combined into 10 fractions and desalted on C18 Cartridges (Sigma, Steinheim, Germany). Each SCX salt step fraction was dried in a vacuum centrifuge and reconstituted with $40 \mu \mathrm{L}$ of $0.1 \%(\mathrm{v} / \mathrm{v})$ trifluoroacetic acid.

\section{LC-ESI-MS/MS analysis}

Five-microgram peptide mixtures were loaded onto a Thermo EASY-nLC column (Thermo Finnigan, San Jose, CA, USA) (100 mm $\times 75 \mu \mathrm{m}, 3 \mu \mathrm{m}$-C18) in Buffer C (0.1\% formic acid) and separated with a linear gradient of Buffer D (84\% acetonitrile with $0.1 \%(\mathrm{v} / \mathrm{v})$ formic acid) at a flow rate of $300 \mathrm{~nL} / \mathrm{min}$ over 120 min: 0-110 min with 0\%-50\% solvent D; $110-114$ min with 50\%-100\% solvent D; $114-120$ min with $100 \%$ solvent D. The Q-Exactive (Thermo Finnigan) mass spectrometer acquired data in the positive-ion 


\section{Cellular Physiology Cell Physiol Biochem 2017;44:1509-1525

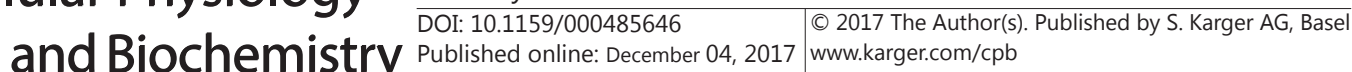

Xu et al.: Grb2 Mediate Mechanotranduction in Chondrocytes

mode, with a selected mass range of 300-1800 mass/charge (m/z). Dynamic exclusion was used with $30.0 \mathrm{~s}$ duration. Q-Exactive survey scans were set as 70,000 at m/z 200 and 17, 500 at m/z 200 of resolution for higher energy collisional dissociation spectra. MS/MS data were acquired using a data-dependent acquisition method using the top 10 most abundant precursor ions. The normalized collision energy was $30 \mathrm{eV}$ and the underfill ratio was defined as $0.1 \%$ on the Q-Exactive.

\section{Protein identification and quantification}

Protein identification was practiced using the MASCOT search engine (version 2.2; Matrix Science, London, UK) embedded into Proteome Discoverer 1.4 (Thermo Electron, San Jose, CA, USA), searching against the Uniprot database of rat protein sequences (uniprot_rat_33675_20141101.fasta). Protein identification was carried out using the following parameters: peptide mass tolerance $= \pm 20 \mathrm{ppm}$; fragment mass tolerance = $0.1 \mathrm{Da}$; enzyme: trypsin; maximum missed cleavage = 2; fixed modification: carbamidomethyl (C); iTRAQ 8plex (K); iTRAQ 8plex (N-term); and variable modification: oxidation (M); FDR $\leq 0.01$ [47].

\section{Bioinformatics analysis}

The sequence data for the selected differentially expressed proteins were retrieved in batches from the UniProtKB database (Version: 201504) in FASTA format. The retrieved sequences were locally searched against the SwissProt Mammal database (rat) using NCBI BLAST client software (ncbiblast-2.2.28win32.exe) to find homologous sequences, to allow the identified sequences to be functionally annotated. Following annotation, the differentially expressed proteins were blasted against Kyoto Encyclopedia of Genes and Genomes (KEGG) genes (rat) using the KEGG automatic annotation server to retrieve their KEGG orthologous identifications, followed by mapping to pathways in KEGG.

\section{Lentivirus transfection}

Chondrocytes were plated at a concentration of $10^{5}$ cells/well into six-well plates and allowed to adhere for 1 day before transfection, as above. The following day, the cells were transfected with Lv-Grb2 vector, Lv-Grb2-RNAi vector, Lv-integrin $\beta 1$-RNAi vector, or their respective control vectors (negative shRNA vector and blank vector) in serum-free medium. At $12 \mathrm{~h}$ after transfection, all the media were changed to complete medium. Three days after transfection, GFP expression was detected by fluorescence microscopy and the expression of targeted genes and proteins was assessed by RT-PCR and western blot analysis.

\section{Direct cell counting}

Cells were trypsinized and counted according to published protocols ${ }^{4}$. Differently pretreated chondrocytes were seeded onto glass slides $(25 \mathrm{~mm} \times 25 \mathrm{~mm})$ coated with type II collagen at a density of $10^{5}$ cells, and divided randomly into non-pressure- and pressure-treated groups. After 3 days culture, cells were trypsinized and counted, and the cell number was determined by counting cells from each glass slide independently.

\section{CCK-8 assay}

Cell proliferation was determined using CCK-8 solution according to the manufacturer's instructions (Dojindo Lab., Kumamoto, Japan). Cells were added to $10 \mu \mathrm{L}$ CCK-8 solution in each well of five 96-well plates $(n=6)$ and incubated for $4 \mathrm{~h}$ at $37^{\circ} \mathrm{C}$. The absorbance of each well was determined at $450 \mathrm{~nm}$ using a microplate reader.

\section{Quantitative real-time PCR ( $q$ PCR) analysis}

Total RNA was extracted using TRIzol reagent (Invitrogen, San Diego, CA, USA) according to the manufacturer's protocol, and quantification of mRNAs was performed using SYBR Green. GAPDH mRNA was used as a housekeeping gene and relative expression levels of mRNAs were calculated using the comparative $\Delta \Delta$ CT method.

\section{Western blot analysis}

Total protein was prepared and western blot analyses were performed as described previously [48]. Total protein was prepared using RIPA buffer, and protein concentrations were determined using the BCA assay. Protein samples were resolved using SDS-polyacrylamide gel electrophoresis, and transferred to 


\section{Cellular Physiology Cell Physiol Biochem 2017;44:1509-1525 and Biochemistry Published online: December 04, 2017 www.karger.com/cpb \\ Xu et al.: Grb2 Mediate Mechanotranduction in Chondrocytes}

nitrocellulose membranes. Following blocking for $1 \mathrm{~h}$ with $5 \%$ skimmed milk in TBST, membranes were incubated with antibodies (1:1, 000 dilutions for all antibodies) overnight at $4{ }^{\circ} \mathrm{C}$. Blots were incubated with HRP-conjugated secondary antibody at ambient temperature for $1 \mathrm{~h}$, and colors were subsequently developed with ECL. Results were scanned using a gel imaging system (UVP LLC, Upland, CA, USA) and measured using Gel-Pro Analyzer software (Media Cybernetics, Rockville, MD, USA).

Gross morphology and wet weight

The constructs harvested from the Lv-Grb2, Lv-Grb2-RNAi, and Lv-GFP (GV358) groups were continuously detected by photography to evaluate macroscopic morphology. At the end of the 6-week culture period, differences in wet weight between specimens were assessed using an electronic balance.

\section{GAG content}

The GAG content of each group was recorded after 6 weeks, as described previously ${ }^{[40]}$. The samples were rinsed with double-distilled $\mathrm{H} 2 \mathrm{O}$ and lyophilized for $12 \mathrm{~h}$, followed by the addition of $1 \mathrm{~mL}$ cold $\mathrm{H}_{2} \mathrm{O}$ and incubation at $4^{\circ} \mathrm{C}$ in a microcentrifuge tube overnight. After lysing by repeated cycles of freeze-thawing and sonication, samples were centrifuged at 8, $000 \mathrm{rpm}$ for $3 \mathrm{~min}$. The supernatants were collected and 25 $\mathrm{mL}$ of the supernatant was mixed with $5 \mathrm{~mL} \mathrm{NaCl}(2.3 \mathrm{M})$ and $200 \mathrm{~mL}$ 9-dimethylmethylene blue chloride solution (Sigma-Aldrich). The absorption at $520 \mathrm{~nm}$ was then measured using a spectrophotometer. A standard curve of known concentrations of chondroitin sulfate B (Sigma-Aldrich) was run concurrently and used to determine the concentrations of unknown samples.

\section{Histological and immunohistochemical analyses}

The glass coverslips with chondrocytes or engineered cartilage samples were washed with phosphatebuffered saline (PBS) and fixed in formalin. Engineered cartilage samples were then embedded in paraffin and cut into 4- $\mu$ m thick sections and stained with hematoxylin-eosin (HE) and safranin-O. For immunohistochemical analysis of type II collagen, deparaffinized sections were incubated with $\mathrm{H}_{2} \mathrm{O}_{2}$ and methanol for 10 min to block endogenous peroxidase, and then incubated for 30 min with serum-blocking solution. The sections were then incubated with primary antibodies (Abcam, ab34712, 1:200 dilutions for all antibodies) for $1 \mathrm{~h}$, followed by incubation with HRP-conjugated anti-rabbit secondary antibodies for $30 \mathrm{~min}$. Bound antibodies were visualized by incubation with DAB for $10 \mathrm{~min}$. All the incubations were performed at room temperature.

\section{Scaffold preparation}

To promote cell attachment, scaffolds (length $8 \mathrm{~mm}$, height $2 \mathrm{~mm}$ polylactide-polyglycolic acid 9:1, porosity $90 \%$; pore size $100 \mu \mathrm{m}$ ) were pre-immersed in polylysine, sterilized with ethylene oxide, rinsed with PBS, dried, and stored in a desiccator before cell seeding.

\section{In vitro construction of engineered cartilage}

Rat chondrocytes at passage two were seeded into the scaffolds at a density of $5 \times 10^{7}$ cells $/ \mathrm{cm}^{3}$, with a total of $6.4 \times 10^{6}$ cells per scaffold. To promote complete adhesion of cells to the scaffolds, the cell-scaffold constructs were then incubated at $37^{\circ} \mathrm{C}$ under $5 \% \mathrm{CO}_{2}$ for $4 \mathrm{~h}$, covered with DMEM-F12 supplemented with $10 \% \mathrm{FBS}$, and then incubated at $37^{\circ} \mathrm{C}$ with $5 \% \mathrm{CO}_{2}$. The medium was replaced every 2 days and the constructs were cultured for up to 6 weeks for further evaluation.

\section{Results}

\section{Proteomic analysis and validation}

We used iTRAQ combined with LC-MS/MS to identify differentially expressed proteins in chondrocytes under periodic mechanical stress. To ensure high quality of samples, we verified the effectiveness of the compression first. After 3 days of pressurization, we determined aggrecan and collagen II expression by qPCR analysis, and detected chondrocytes proliferation via cell counting and CCK-8 assay. In line with our previous research, pressure increased expression levels of aggrecan and collagen II in chondrocytes and promoted their proliferation (Fig. 1). 


\section{Cellular Physiology Cell Physiol Biochem 2017;44:1509-1525

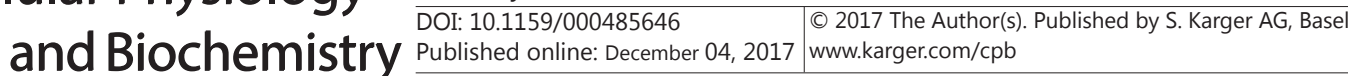

Fig. 1. Periodic mechanical stress promoted chondrocyte proliferation and matrix synthesis. (A, B) Aggrecan and collagen II gene expression detected by real-time PCR assay. (C, D) Direct cell counting and cell counting kit-8 (CCK-8) assay of chondrocytes. Data are represented as mean $\pm \mathrm{SD}$. $\left(\mathrm{n}=5,{ }^{*} \mathrm{p}<0.01\right)$.

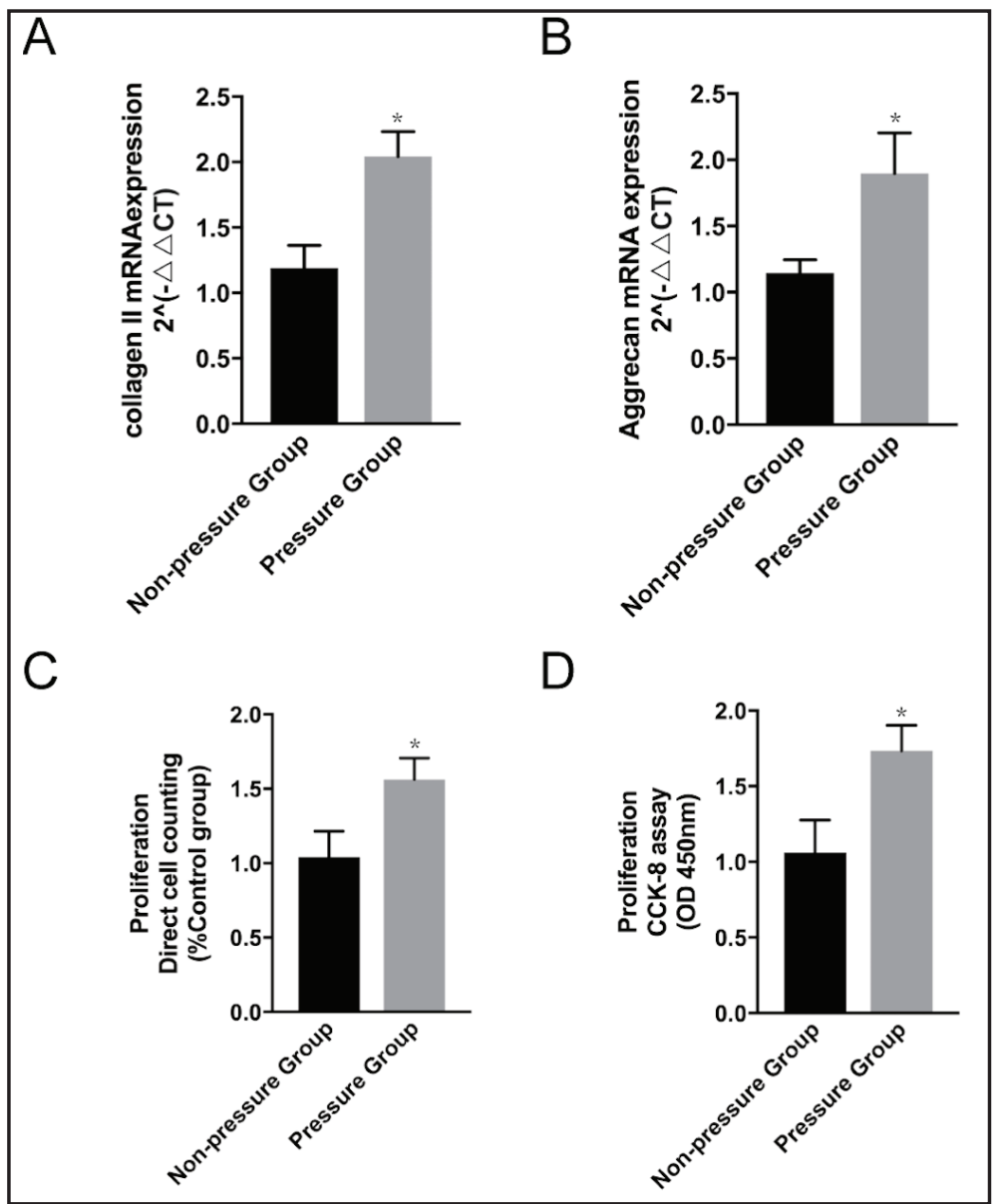

Table 1. Characteristics of proteins selected to confirm the proteomic analysis

\begin{tabular}{|c|c|c|c|c|c|}
\hline Accession & Gene & Protein & $\begin{array}{c}\text { Fold } \\
\text { change } \\
\text { B/A }\end{array}$ & $\begin{array}{c}\text { p- } \\
\text { value }\end{array}$ & Main function \\
\hline P62994 & Grb2 & Growth factor receptor-bound protein 2 & 1.490 & 0.02 & $\begin{array}{c}\text { regulation of MAPK cascade } \\
\text { Ras protein signal transduction }\end{array}$ \\
\hline Q62879 & Ppard & PPAR delta protein & 1.452 & 0.015 & $\begin{array}{l}\text { positive regulation of cell } \\
\text { proliferation }\end{array}$ \\
\hline Q62862 & Map2k5 & $\begin{array}{l}\text { Dual specificity mitogen-activated protein } \\
\text { kinase kinase } 5\end{array}$ & 1.292 & 0.018 & $\begin{array}{l}\text { activation of MAPK activity } \\
\text { positive regulation of cell } \\
\text { growth }\end{array}$ \\
\hline A1L1M0 & Prkaca & $\begin{array}{l}\text { Protein kinase, cAMP-dependent, catalytic, } \\
\text { alpha }\end{array}$ & 1.224 & 0.023 & $\begin{array}{c}\text { activation of protein kinase } \mathrm{A} \\
\text { activity }\end{array}$ \\
\hline F1M2P8 & Prkca & Protein kinase $\mathrm{C}$ & 1.212 & 0.026 & regulation of MAPK cascade \\
\hline
\end{tabular}

We then digested equal amounts of proteins from normal and mechanical stressed chondrocytes with trypsin and labeled the resulting peptide mixture with iTRAQ reagents. The iTRAQ-labeled peptides were fractionated by SCX chromatography and the eluted fractions were analyzed by LC-MS/MS. The recognized peptides were then searched against the UniProt Knowledgebase. A total of 5468 proteins (1 peptide) were identified. Fold changes of protein expression were determined as the ratios of iTRAQ reporter ions between the normal and stressed samples. Using a threshold (B/A) of 1.2-fold change and a p value 


\section{Cellular Physiology Cell Physiol Biochem 2017;44:1509-1525

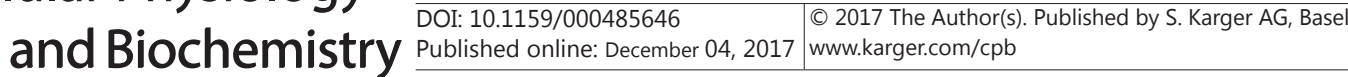

Fig. 2. Verification of proteomic analysis results by western blotting and realtime PCR. (A) Representative western blots and quantification of PKC, PPAR $\delta$, MEK5, PKAc $\alpha$, and Grb2. (B) Relative gene expression levels assessed by real-time PCR. Data are represented as mean \pm SD. $(n=5$, ${ }^{*} \mathrm{p}<0.05, \quad{ }^{* *} \mathrm{p}<0.01$, $* * * \mathrm{p}<0.001)$.

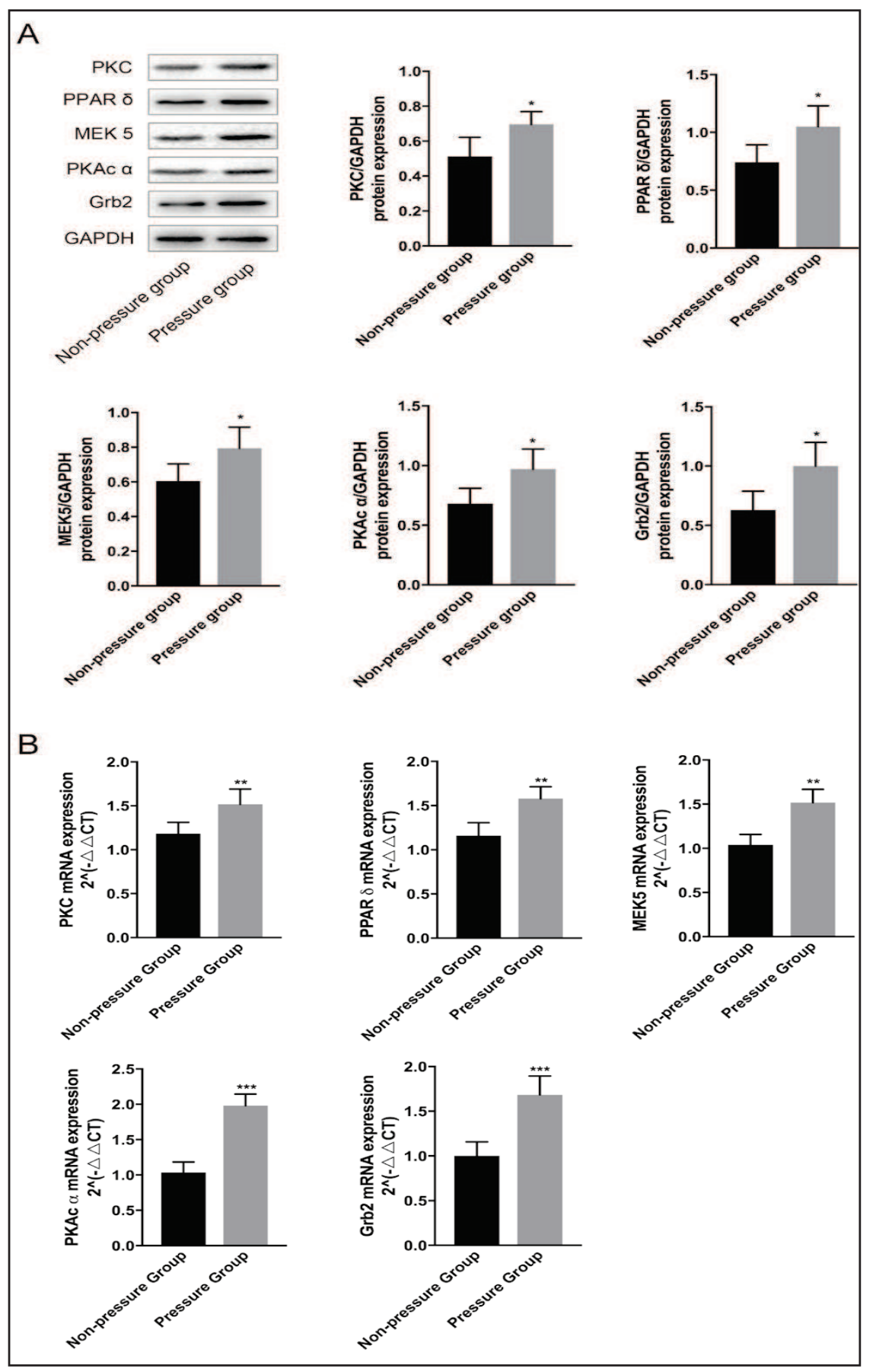

$\leq 0.05,485$ proteins (168 up-regulated and 317 down-regulated) were extracted, among which 155 (40 up-regulation and 115 down-regulation) proteins have been detected as integrin adhesome components in other researches [18]. To confirm the mass spectrometry results, we selected five differentially expressed proteins (PKC, PPAR $\delta$, MEK5, PKAc $\alpha$, Grb2; see Table 1) to examine by western blot and real-time PCR(Fig. 2).

\section{Bioinformatics analysis}

All 485 differentially expressed proteins were subsequently classified by bioinformatics analysis. The gene ontology (GO) database is an internationally standardized gene functional classification system that comprehensively describes the characteristics of different genes and 


\section{Cellular Physiology \\ Cell Physiol Biochem 2017;44:1509-1525 and Biochemistry Published online: December 04, 2017 www.karger.com/cpb

Fig. 3. Bioinformatics analysis summary. Classification of proteins into secondlevel GO terms including biological process, cellular component, and mole cular function. (B) Top 20 KEGG pathways associated with differentially expressed proteins.
A

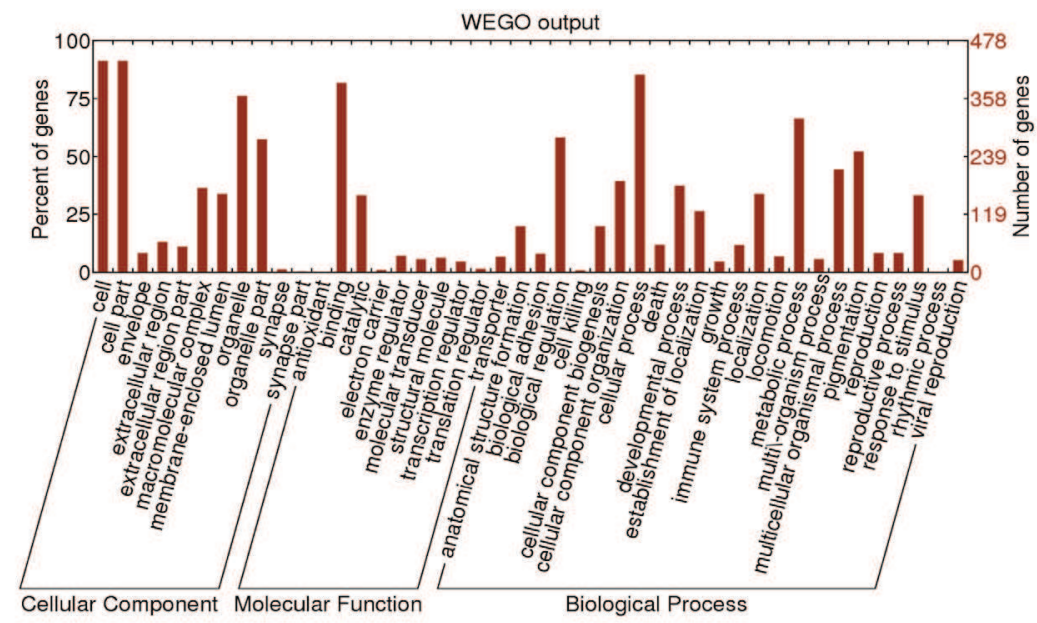

B

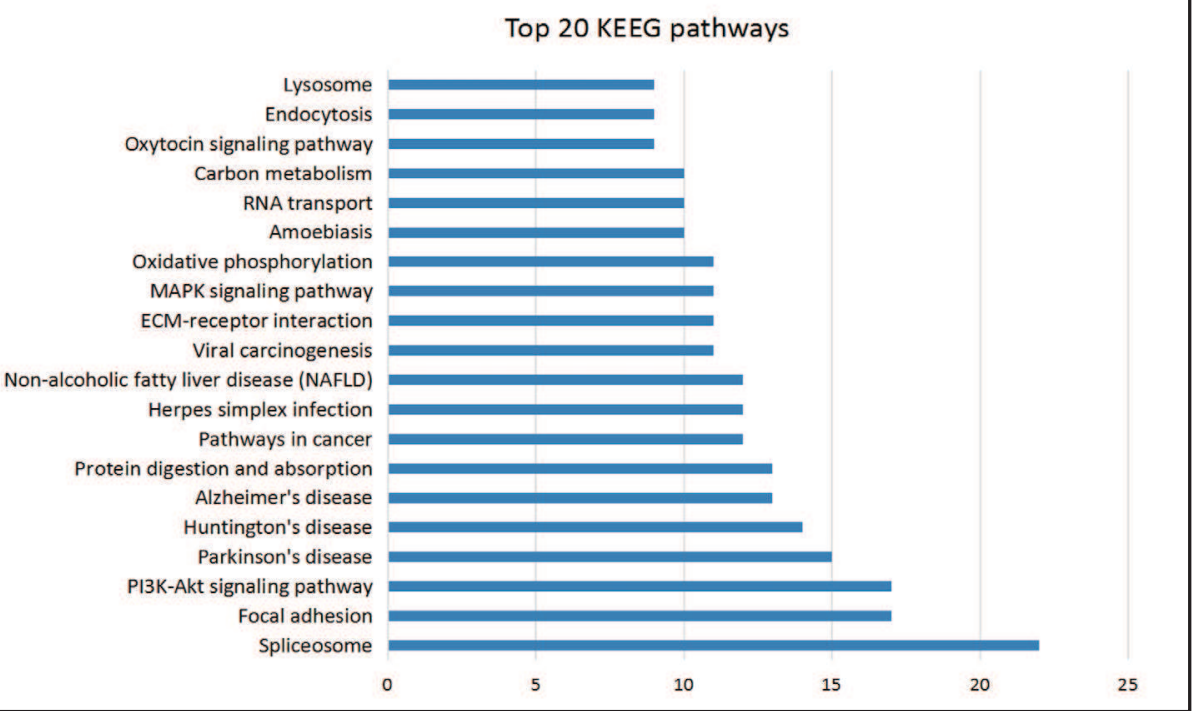

their products [19]. A total of 479 differentially expressed proteins in stressed chondrocytes were annotated to $5691 \mathrm{GO}$ function entries. Second-level GO terms were applied to classify proteins in terms of their involvement in three main categories (biological process, cellular component, and molecular function) and each protein was assigned at least one term. More than $75 \%$ ( 429 proteins) were annotated as belonging to the cell compartment, and the other two main categories of these proteins were the organelle (368 proteins) and membrane (334 proteins) compartments. The top three molecular functions were binding (393 proteins), catalytic activity (160 proteins), and hydrolase activity (61 proteins), and the top three biological processes identified were cellular process (411 proteins), singleorganism process (352 proteins), and metabolic process (331 proteins) (Fig. 3).

Considering that different proteins interact and cooperate to complete biochemical reactions, KEGG pathway-based analysis was performed to identify pathways potentially affected by cyclic pressure [20]. The top three pathways identified were the spliceosome ( 22 proteins, $\mathrm{p}<0.01$ ), focal adhesion $(17$ proteins, $\mathrm{p}<0.01$ ), and the PI3K-Akt pathway (17 proteins, $\mathrm{p}<0.01$ ) (Fig. 3). There were also 11 differentially expressed proteins involved in the MAPK signal pathway, which has an established role in periodic mechanical stress transduction. 


\section{Cellular Physiology Cell Physiol Biochem 2017;44:1509-1525

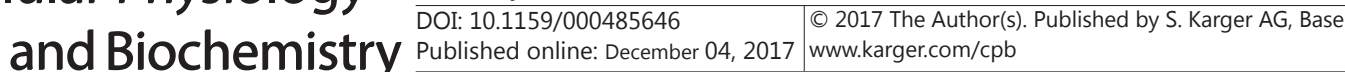 \\ Xu et al.: Grb2 Mediate Mechanotranduction in Chondrocytes}

Fig. 4. Estimation of transfection efficiency in chondrocytes. (A) Representative pictures of chondrocytes under light and fluorescence microscopy (100x). (B) Representative western blots and Grb2 mRNA expression levels after lentivirus transfection in different groups. Grb2 played a role in signaling of periodic mechanical stress in chondrocytes. (C, D) Direct cell counting and cell counting kit-8 (CCK-8) assay of chondrocytes with differentially expressed Grb2 with or without pressure. (E, F) Aggrecan and collagen II gene expression detected by real-time PCR assay in chondrocytes. (G) Representative immunohis tochemistry images stained for collagen $(100 \times)$. Data are represented as mean \pm SD. $(n=5, * \mathrm{p}<0.05$, $* * \mathrm{p}<0.01)$.

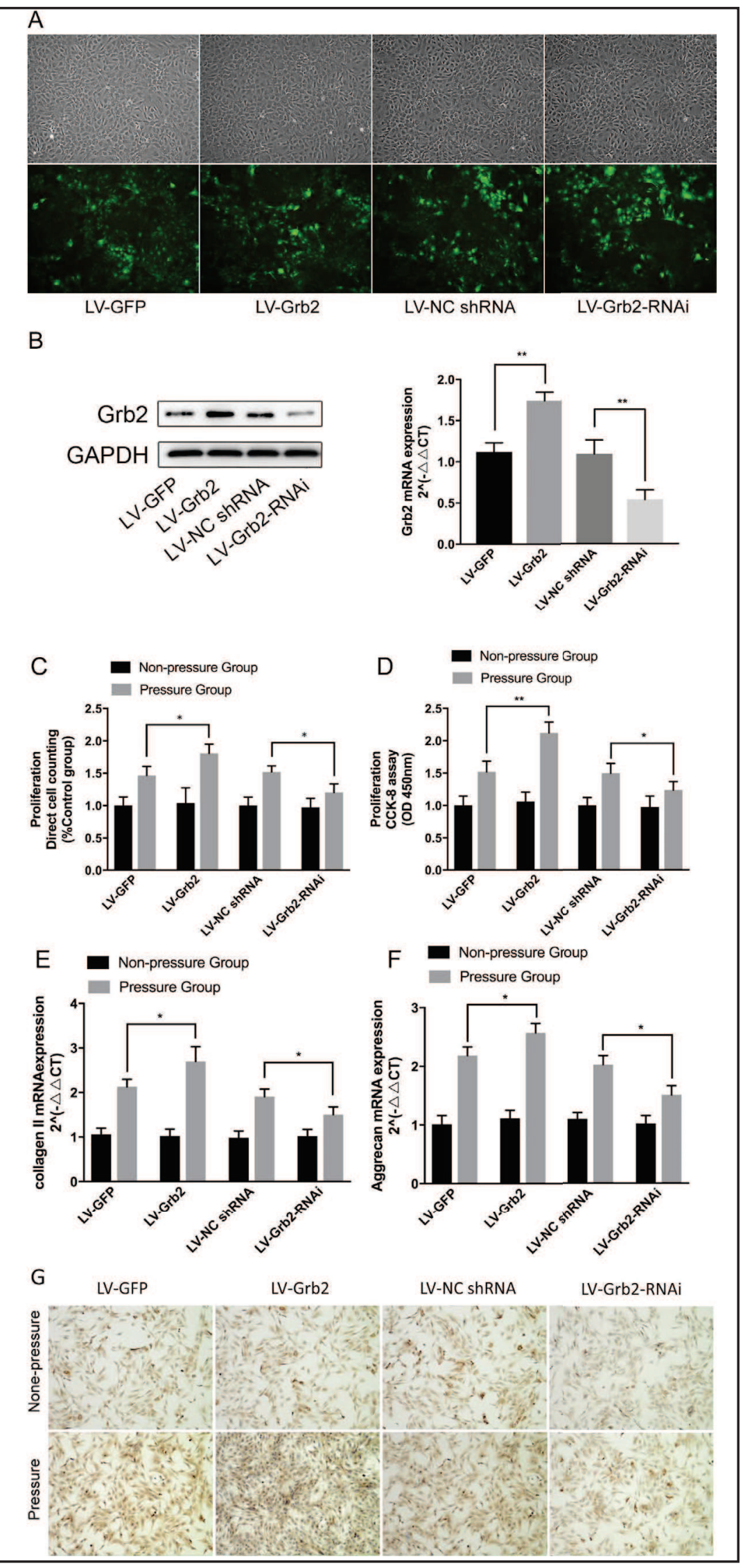




\section{Cellular Physiology Cell Physiol Biochem 2017:44:1509-1525 and Biochemistry Published online: December 04, 2017 www.karger.com/cpb \\ Xu et al.: Grb2 Mediate Mechanotranduction in Chondrocytes}

\section{Effects of Grb2 on mechanotransduction in chondrocyte}

Among proteins related to cell growth and proliferation, Grb2 was obviously increased under the influence of pressure. Notably, this protein has been reportedly associated with mechanical stress signal transduction in other cells [21-23]. We therefore transfected chondrocytes with the lentivirus vectors Lv-Grb2-RNAi and Lv-Grb2 to up-regulate or down-regulate the expression of Grb2, to determine its role in periodic mechanical stressinduced cellular response in chondrocytes. Lentivirus vectors containing negative shRNA or containing GFP alone were used as controls. We evaluated GFP expression 3 days after transfection by fluorescence microscopy. More than $80 \%$ of chondrocytes were effectively transfected, suggesting a high transfection efficiency (Fig. 4A). Western blot results suggested Lv-Grb2 significantly enhanced the expression of Grb2, while Lv-Grb2-RNAi suppressed it (Fig. 4B). We also tested the effects of lentivirus transfection at the genetic level by qPCR, which produced results consistent with western blotting (Fig. 4B).

After lentivirus pretreatment, we examined the proliferation and matrix synthesis of chondrocytes exposed to mechanical stress or under static conditions. Stimulation by cyclical stress strongly increased chondrocyte proliferation, as well as aggrecan and type II collagen gene expression levels in the Lv-Grb2 group compared with the Lv-GFP group, while the opposite results were obtained in the Lv-Grb2-RNAi group (Fig. 4C-4F). Immunocytochemical staining to measure collagen II levels produced results in accord with those of qPCR (Fig. 4G).

\section{The molecular mechanisms of Grb2 medicating mechnosensory process}

Grb2 has been known to play a positive role in receptor tyrosine kinase signaling [24, 25], and the association of Grb2 and Shc/FAK is upstream to the activation of MAPK, which is an important signaling pathway leading to the proliferation and matrix synthesis of chondrocytes when exposed to periodic mechanical stress [26,27]. We therefore hypothesized that the effect of Grb2 in mechanical signal transduction in chondrocytes may be related to the stimulation of MAPK pathway. To clarify the molecular mechanisms of mechnosensory process, we observed the phosphorylation status of Shc (Fig. 5a), FAK (Fig. 5B) and ERK1/2 (Fig. 5C) in chondrocytes under periodic mechanical stress or static conditions, using western blotting. The results suggested that FAK and ERK1/2 were phosphorylated while Shc were not. Their activations were relatively increased and decreased in the Lv-Grb2 and Lv-Grb2-RNAi groups, respectively, compared with the Lv-GFP or Lv-NC shRNA groups, when exposed to cyclic mechanical stress, whereas their activations were unaffected in stationary culture

Integrin is the main mechanical signaling receptor on the cell surface and plays an important role in mechanical stress signaling [28-30]. We thus studied the relations between Grb2 up-regulation and integrin in integrin $\beta 1$ defect chondrocytes under pressure. We down-regulated integrin $\beta 1$ expression using a lentivirus vector (Lv-integrin $\beta 1$ ), with an empty vector ( $\mathrm{Lv}$-GFP) as a control. The effectiveness of lentivirus transfection determined by fluorescence microscopy was $>80 \%$ (Fig. $6 \mathrm{~A}$ ). Western blot and qPCR showed that integrin expression was successfully reduced (Fig. 6A). The mechanical stress-induced increase in Grb2 expression was inhibited in the integrin $\beta 1$ down-regulated group compared with the control group, while there was no significant difference between the two groups under static conditions (Fig. 6B). ERK1/2 expression showed the same pattern as Grb2, irrespective of pressure (Fig. 6B). To verify the above theory, we used blebbistatin to block the mechanical maturation of focal adhesions, the Western blot and qPCR results showed the increase of Grb2 expression initiated by mechanical stress were inhibited (Fig. 6C).

\section{Effects of up-regulation Grb2 on construction of tissue-engineered cartilage under periodic} mechanical stress in vitro

Having demonstrated the role of Grb2 in signal transduction of cyclic mechanical stress, we explored if overexpression of Grb2 increased the quality of tissue-engineered cartilage in vitro. We evaluated the effects of Grb2 expression on 3D cartilage formation by chondrocytes in 


\section{Cellular Physiology Cell Physiol Biochem 2017;44:1509-1525 \begin{tabular}{lll}
\hline DOI: 10.1159/000485646 2017 The Author(s). Published by S. Karger AG, Basel \\
\hline
\end{tabular} and Biochemistry Published online: December 04, 2017 www.karger.com/cpb

Fig. 5. Grb2-mediated mechanotransduction in chondrocytes via FAK and ERK1/2 activity. (A) Representative western blots and quantification of $\mathrm{p}$-Shc and Shc under two different environments.

(B,

C) Representative western blots of $\mathrm{p}$ FAK (Tyr397 and Tyr576/577) and FAK, p-ERK1/2 and ERK1/2 in Grb2 upregulated or downregulated groups with or without exposure to pressure. Quantification of $\mathrm{p}$ ERK normalized to total ERK1/2 are also showed. Data are represented as mean \pm SD. $\left(\mathrm{n}=5,{ }^{*} \mathrm{p}<0.05\right)$.
A
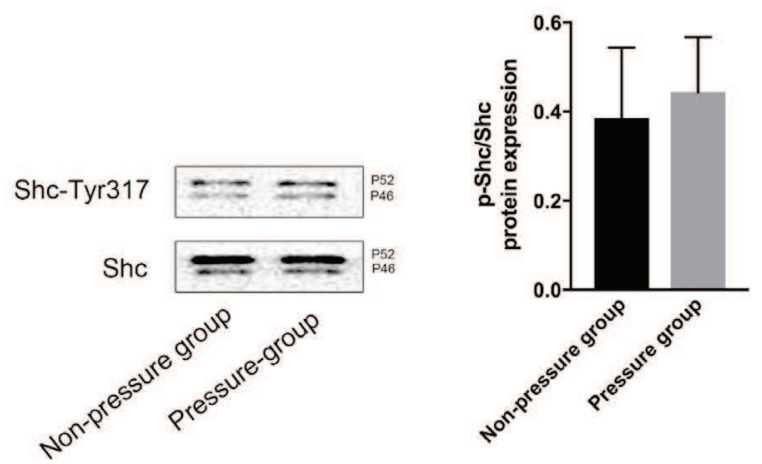

B
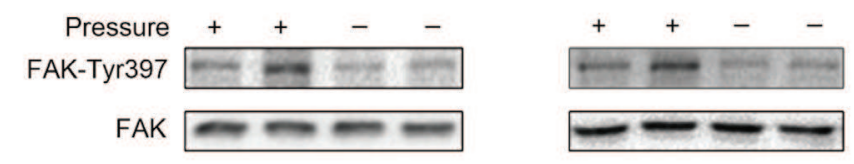

FAK-Tyr576/577 bintions
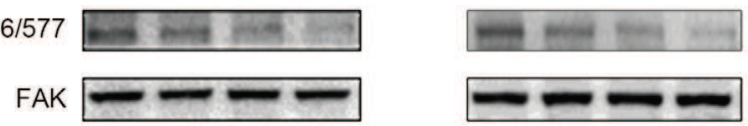

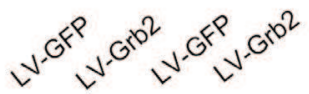
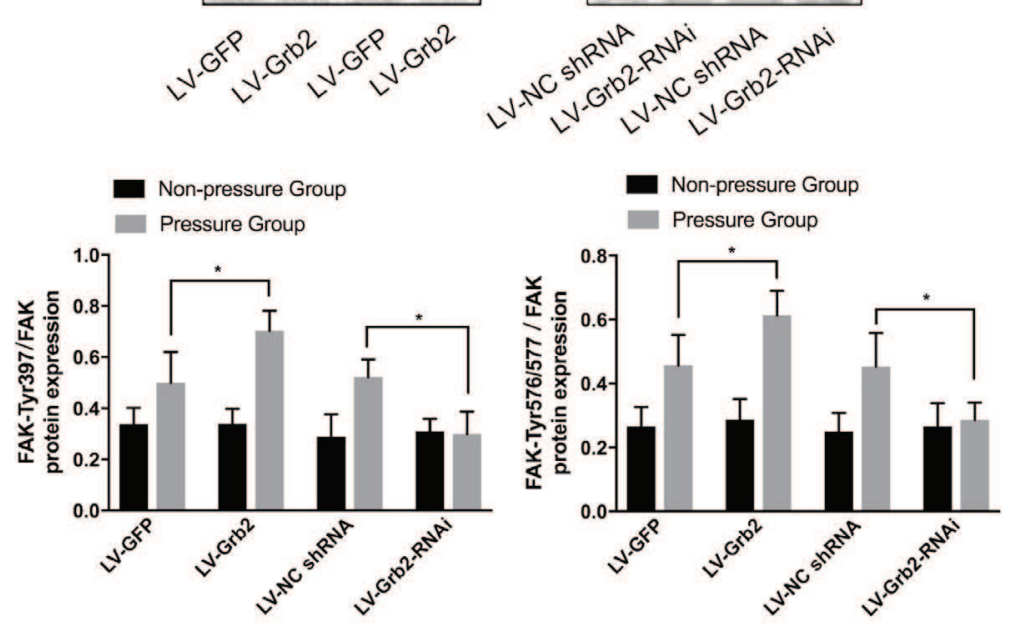

C

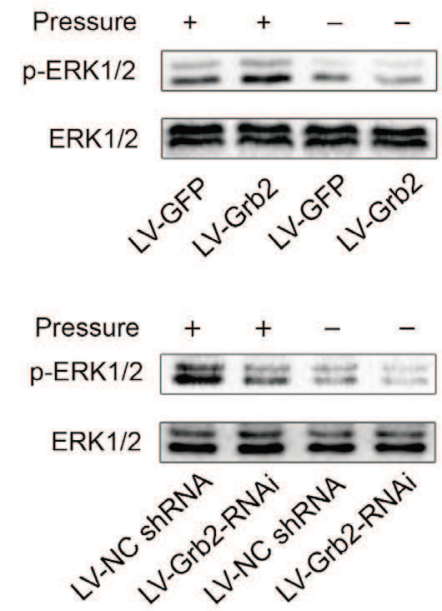




\section{Cellular Physiology Cell Physiol Biochem 2017;44:1509-1525 and Biochemistry DOI: 10.1159/000485646 2017 ( 2017 The Author(s). Published by S. Karger AG, Basel

Fig. 6. Integrin $\beta 1$ mediates elevated expression of Grb2 in chondrocytes induced by periodic mechanical stress. (A) Estimation of transfection efficiency by fluorescence microscopy (200x), western blot, and real-time PCR. (B) Representative western blots and quantification of Grb2 and pERK in integrin $\beta 1$-knockdown groups with or without exposure to mechanical stimuli. (C) Representative western blots and quantification of Grb2 under pressure in the existence of blebbistatin or not. Data are represented as mean \pm SD. $\left(\mathrm{n}=5,{ }^{*} \mathrm{p}<0.05\right)$.

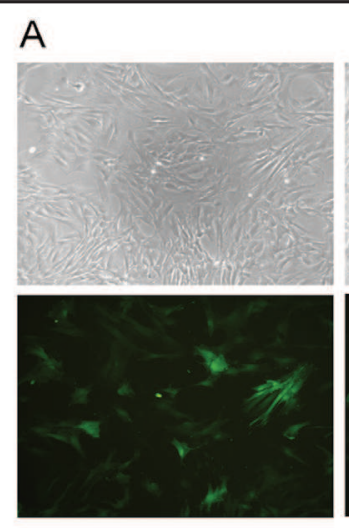

LV-NC shRNA

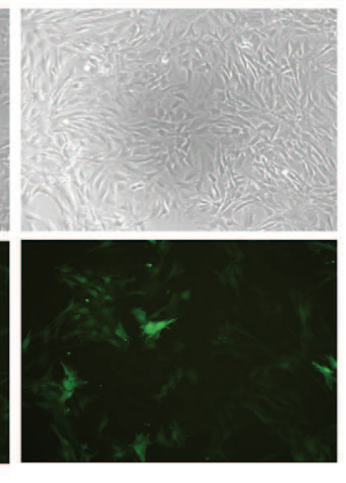

LV-integrin $\beta 1$

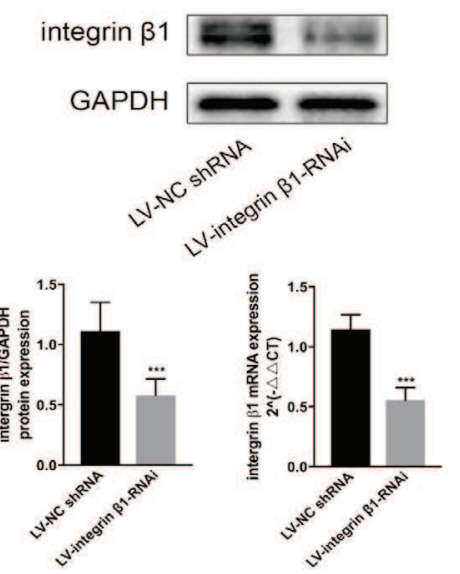

B
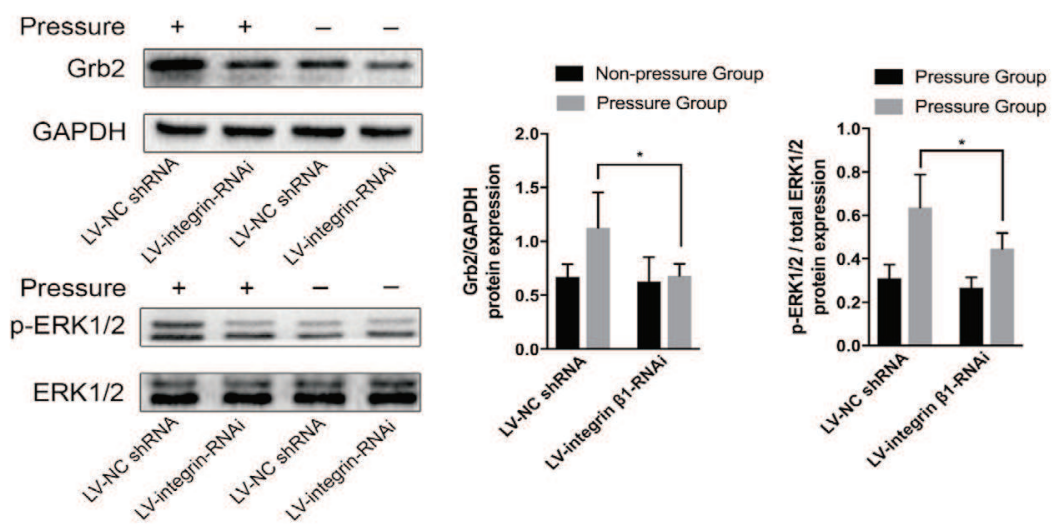

C
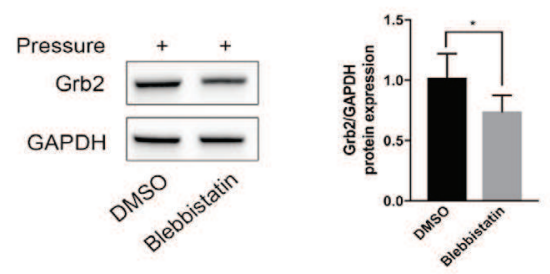

a scaffold after 6 weeks of culture under periodic mechanical stress and recorded differences in gross morphology and size, wet weight, and GAG content among the three groups. Cartilagelike tissue was formed in all three groups (Fig. 7A), but the wet weight (Fig. 7B) and the GAG content (Fig. 7C)of the cartilage were gradually increase in Grb2 overexpression group. We further examined the engineered cell/scaffold constructs formed under periodic mechanical stress by staining with $\mathrm{HE}$ and safranin-O, the immunocytochemical staining for collagen II was also be used. We observed typical cartilaginous metachromasia in engineered tissues (Fig. 7D-7L). All the staining methods demonstrated that more chondrocyte-like cells with surrounding lacunae formed in the Lv-Grb2 group in response to periodic mechanical stress, while the Lv-Grb2-RNAi group showed the opposite results (Fig. 7D-7L). Safranin-O staining was stronger in the Lv-Grb2 group but weaker in the Lv-Grb2-RNAi group compared with the control group (Fig. 7G-7I). Immunocytochemical staining for type II collagen showed a similar pattern to the other two staining methods (Fig. 7J-7L). 


\section{Cellular Physiology \\ Cell Physiol Biochem 2017;44:1509-1525 \\ \begin{tabular}{ll|l} 
and Biochemistry & Dublished online: December 04, 2017 & $\begin{array}{l}\text { @ } 2017 \text { The Author(s). Published by S. Karger AG, Basel } \\
\text { www.karger.com/cpb }\end{array}$ \\
\hline
\end{tabular}}

Xu et al.: Grb2 Mediate Mechanotranduction in Chondrocytes

Fig. 7. Up-regulated Grb2 improved the quality of tissue-engineered cartilage in vitro. (A) Representative images of tissue-engineered cartilage based on polylactide-polyglycolic acid scaffold constructed by chondrocytes with different levels of Grb2 expression after 6 weeks culture under pressure. (B, C) Wet weight and GAG content of tissueengineered cartilage in the three groups after 6 weeks culture under pressure. (D, E, F) Representative HE staining. (G, H, I) Representative safranin-O staining. (J, K, L) Representative immunohistochemical staining for collagen type II. Scale bar $=25 \mu \mathrm{M}$.

\section{Discussion}

The mechanosensing and signaling mechanisms in chondrocytes have been researched extensively over the past few years. However, an integrative, systems-wide description of mechanosening is lacking. In the current study, we applied proteomic research to analyze the interactions between the involved proteins in the chondrocytes under pressure and established a proteome profile. As we know, cells perceive information about the biophysical properties of their micro-

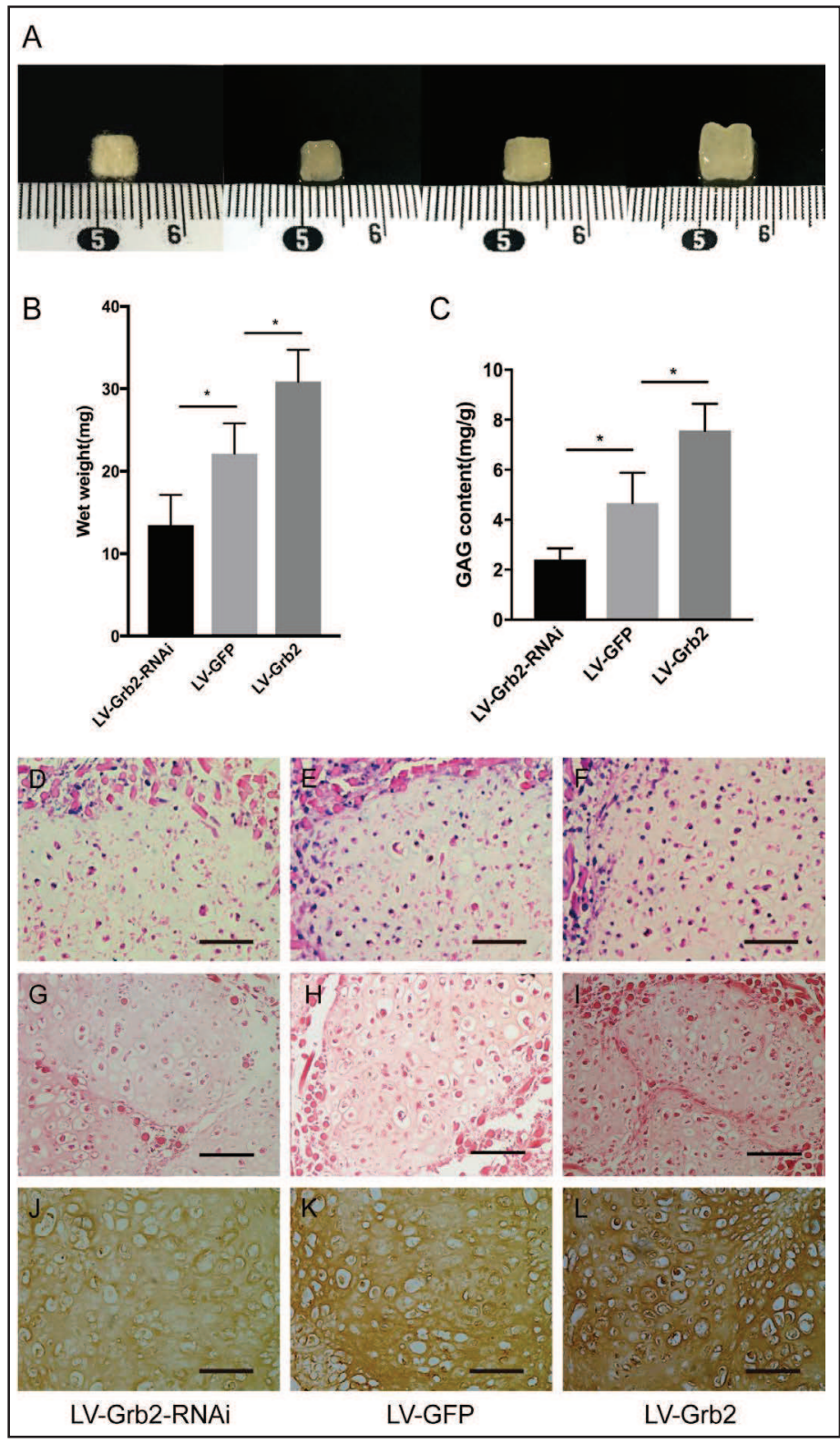
environment through integrinmediated cell-matrix adhesions which comprise a diverse proteins and known as "integrin adhesome". Horton ER et al. have integrated several integrin adhesion complexes proteomes and generated a 2412-protein integrin adhesome [18]. Analysising of this data set we found that $32 \%(155 / 485)$ differentially expressed proteins detected in our proteomic analysis were the components of integrin adhesome, demonstrating that mechanosensing and signaling in chondrocytes may associate with this molecular complex. Grb2, a member of this complex, demonstrated a 1.49-fold change in response to mechanical stress.

Grb2 is an ubiquitous adapter protein expressed in various cells [31]. It plays important roles in many basic cellular functions, such as cell proliferation and angiogenesis, by regulating receptor tyrosine kinase signaling. Also several researches have suggested Grb2 involved in mechanotransduction in some cells. For example, Li et al. in bovine aortic endothelial cells found that shear stress promoted the phosphorylation of FAK and initiated its association with Grb2, which is necessary for activation of ERK and JNK[32]. Similarly, Wang et al. reported that fluid shear stress induced activation of FAK and formation of a FAK-Grb2-Sos ternary complex in MG-63 cells, which eventually phosphorylated ERK and JNK[22]. Zhang 


\section{Cellular Physiology Cell Physiol Biochem 2017:44:1509-1525 and Biochemistry Published online: December 04, 2017 www.karger.com/cpb \\ Xu et al.: Grb2 Mediate Mechanotranduction in Chondrocytes}

et al. demonstrated that Grb2 regulated cardiac hypertrophy and fibrosis in response to pressure overload through the p38 MAPK signaling pathway [21]. Consequently, the function of Grb2 in chondrocytes under periodic mechanical stress was worth investigating.

In this study, we changed Grb2 expression using lentivirus vectors and subjected the transfected chondrocytes to periodic mechanical stress. Proliferation, matrix synthesis and ERK1/2 phosphorylation were all markedly increased in Grb2-overexpressing chondrocytes under periodic mechanical stress, while the opposite effect was obtained in the Grb2 down-regulated group. What's more, the alternation of Grb2 expression did not affect the chondrocytes proliferation or matrix synthesis without mechanical stimulus. These results suggest that periodic mechanical stress is a decisive factor in improving the quality of chondrogenesis, and then the adaptor protein Grb2 is a regulatory factor of this process. Unlike previous studies, our results indicated that mechanical stimuli even can increase the expression of Grb2. This discrepancy was partly due to the ignorance of Grb2 expression in previous works. The diversity of cell types and mechanical stimuli conditions used in those researches may also had impacts.

Though we have confirmed that Grb2 mediated the periodic mechanical stress-induced cellular response in chondrocytes, the upstream and downstream effects of Grb2 remain to be determined. Preliminary studies revealed a canonical model of Grb2 function whereby, after activation and tyrosylphosphorylation, Grb2 combines with Shc or FAK, thus triggering a MAPK cascade [33, 34]. The activation of FAK caused by mechanical stress has been reported in our previous research, so we examined the phosphorylation of Shc additionally and the results showed it seems neutral in mechnosensing. After that, we verified whether the expression of Grb2 influenced FAK(Tyr397 and Tyr576/577) and ERK1/2 phosphorylation under pressure. The results showed Grb2 did affect activation of FAK and ERK1/2, which indicated to a certain extent that FAK and ERK1/2 were the downstream proteins along Grb2 during mechanotransduction. These findings were consist with several studies mentioned above that Grb2 could combine with FAK and induce the phosphorylation of ERK1/2[3537]. Moreover, Cheng et al. detected that integrin-induced FAK-Tyr397 autophosphorylation was suppressed in Grb2 down-regulated fibroblasts, while Levy-Apter reported that Grb2 promoted Src activation via PTP $\epsilon$ and phosphorylate FAK-Tyr576/577[38, 39]. These findings identified Grb2 as a new FAK and Src activator, which could partly point the FAK and ERK1/2 phosphorylation and the subsequent acceleration of chondrocytes proliferation and matrix synthesis in the presence of cyclic mechanical stress.

However, overexpression of Grb2 usually be observed in tumor tissues or pathological cells, the elevated expression in response to mechanical stimuli hasn't been reported yet and the mechanism need to be explored. The adhesive interactions of cells with their environment through the integrin family of transmembrane receptors have key roles in regulating multiple aspects of cellular physiology, including cell proliferation, viability, differentiation and migration16[18]. Given that a clear role for integrins in mechnosensing has been established, and our previously studies revealed that mechanical induced proliferation and matrix synthesis were partly initiated by integrin $\beta 1$ [7-9], we supposed the overexpression of Grb2 was associated with integrin. As expected, we observed the stress-induced enhancement of Grb2 expression was attenuated following integrin $\beta 1$ down-regulation. Besides, we inhibited the mechanical maturation of focal adhesions via blebbistatin and the increase of Grb2 also be controlled. The correlation between integrin and Grb2 was confirmed again by this data.

We previously reported that integrin $\beta 1$ gene therapy enhanced the creation of tissueengineered cartilage under periodic mechanical stress in vitro [40]. That result prompted us to explore if the quality of tissue-engineered cartilage constructed in vitro could be increased by a parallel gene method. As the above results showed, the proliferation, matrix synthesis, and ERK1/2 phosphorylation increased after overexpression of Grb2 in monolayer chondrocyte cultures when exposed to periodic mechanical stress. We therefore detected the effects of Grb2 up-regulation on the quality of 3D tissue-engineered cartilage formed in vitro. We observed that increased Grb2 expression significantly promoted GAG and type 


\section{Cellular Physiology Cell Physiol Biochem 2017;44:1509-1525

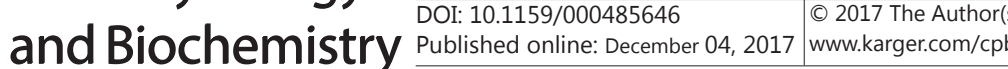 \\ Xu et al.: Grb2 Mediate Mechanotranduction in Chondrocytes}

II collagen synthesis, further confirming that Grb2 up-regulation enhanced the quality of tissue-engineered cartilage in 3D culture exposed to periodic mechanical stress.

In addition to the above, Our iTRAQ data also found other proteins associated with cell proliferation and growth changed under mechanical stress. For example, fetuin A, which increased nearly two-fold in chondrocytes exposed to periodic mechanical stress, has been shown to increase fibroblast proliferation [41], while syntenin-1, which showed a 1.28-fold increase, also has been confirmed associated with the proliferation of various cells [42-44]. Further studies are needed to determine if these proteins are involved in mechanotransduction in chondrocytes under periodic mechanical stress.

The present study provided the first systematic proteomic analysis of chondrocytes under cyclic mechanical stimuli. However, it was subject to some limitations. The current quantitative proteomic analysis just distinguished differences in protein expression between pressure-treated and non-pressure groups, and did not detect differences in protein phosphorylation. The detailed and precise mechanisms responsible for the periodic mechanical stress-induced increase in Grb2 expression thus awaits further investigation. Furthermore, more studies are needed to investigate the construction of high-quality tissueengineered cartilage constructed as a result of Grb2 up-regulation in vivo.

\section{Conclusion}

We identified the differentially expressed proteome profiles of rat chondrocytes under periodic mechanical stress compared with non-stressed conditions. These profiles will form the basis for further studies of the mechanisms underlying the mechanosensing abilities and responses of chondrocytes to periodic mechanical stress. The results also demonstrated a key role for Grb2 in chondrocyte responses to periodic mechanical stimuli. Grb2 up-regulation could thus enhance the quality of tissue-engineered cartilage, providing a new approach to building high-quality tissue-engineered cartilage in vitro.

\section{Acknowledgements}

This work was supported by the National Natural Science Foundation of China (grant numbers 81271986, 81672169, 81472079). S.X., Z.L., Z.W., C.J.Z. and C.H.Z. performed the experiments; W.M.F., S.X. and W.W.L. designed the study; S.X. wrote the manuscript. All authors read and approved the final manuscript. Statistical analyses were performed using SPSS 14.0 software. The results are expressed as mean \pm standard deviation. Student's unpaired t-tests and two-way analysis of variance (ANOVA) were used to determine statistical significance. A $\mathrm{p}$ value $<0.05$ was considered significant.

\section{Disclosure Statement}

The authors declare no competing financial interests.

\section{References}

1 Jung Y, Kim SH, Kim SH, Kim YH, Xie J, Matsuda T, Min BG: Cartilaginous tissue formation using a mechanoactive scaffold and dynamic compressive stimulation. J Biomater Sci Polym Ed 2008;19:61-74.

2 Akimoto T, Kawanishi M, Ushida T: [Mechanical stress and tissue engineering]. Clin Calcium 2008;18:13131320.

-3 Wang PY, Chow HH, Lai JY, Liu HL, Tsai WB: Dynamic compression modulates chondrocyte proliferation and matrix biosynthesis in chitosan/gelatin scaffolds. J Biomed Mater Res B Appl Biomater 2009;91:143152.

4 Chaturvedi LS, Marsh HM, Shang X, Zheng Y, Basson MD: Repetitive deformation activates focal adhesion kinase and ERK mitogenic signals in human Caco-2 intestinal epithelial cells through Src and Rac1. J Biol Chem 2007;282:14-28. 


\section{Cellular Physiology Cell Physiol Biochem 2017;44:1509-1525

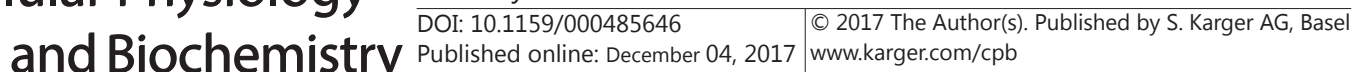

Xu et al.: Grb2 Mediate Mechanotranduction in Chondrocytes

-5 Kock LM, Schulz RM, van Donkelaar CC, Thummler CB, Bader A, Ito K: RGD-dependent integrins are mechanotransducers in dynamically compressed tissue-engineered cartilage constructs. J Biomech 2009;42:2177-2182.

6 He P, Shen N, Gao G, Jiang X, Sun H, Zhou D, Xu N, Nong L, Ren K: Periodic Mechanical Stress Activates PKC 8 Dependent EGFR Mitogenic Signals in Rat Chondrocytes via PI3K-Akt and ERK1/2. Cell Physiol Biochem 2016;39:1281-1294.

7 Nong L, Yin G, Ren K, Tang J, Fan W: Periodic mechanical stress enhances rat chondrocyte area expansion and migration through Src-PLCgamma1-ERK1/2 signaling. Eur J Cell Biol 2010;89:705-711.

8 Ren K, Liu F, Huang Y, Liang W, Cui W, Wang Q, Fan W: Periodic mechanical stress activates integrinbeta1dependent Src-dependent PLCgamma1-independent Rac1 mitogenic signal in rat chondrocytes through ERK1/2. Cell Physiol Biochem 2012;30:827-842.

-9 Liang W, Ren K, Liu F, Cui W, Wang Q, Chen Z, Fan W: Periodic mechanical stress stimulates the FAK mitogenic signal in rat chondrocytes through ERK1/2 activity. Cell Physiol Biochem 2013;32:915-930.

10 Liang W, Li Z, Wang Z, Zhou J, Song H, Xu S, Cui W, Wang Q Chen Z, Liu F, Fan W: Periodic Mechanical Stress INDUCES Chondrocyte Proliferation and Matrix Synthesis via CaMKII-Mediated Pyk2 Signaling. Cell Physiol Biochem 2017;42:383-396.

11 Bougault C, Aubert-Foucher E, Paumier A, Perrier-Groult E, Huot L, Hot D, Duterque-Coquillaud M, MalleinGerin F: Dynamic compression of chondrocyte-agarose constructs reveals new candidate mechanosensitive genes. PLoS One 2012; 7:e36964.

-12 Perino M, Veenstra GJ: Chromatin Control of Developmental Dynamics and Plasticity. Dev Cell 2016;38:610620.

13 Lourido L, Calamia V, Mateos J, Fernandez-Puente P, Fernandez-Tajes J, Blanco FJ, Ruiz-Romero C: Quantitative proteomic profiling of human articular cartilage degradation in osteoarthritis. J Proteome Res 2014;13:6096-6106.

14 Ji YH, Ji JL, Sun FY, Zeng YY, He XH, Zhao JX, Yu Y, Yu SH, Wu W: Quantitative proteomics analysis of chondrogenic differentiation of C3H10T1/2 mesenchymal stem cells by iTRAQ labeling coupled with online two-dimensional LC/MS/MS. Mol Cell Proteomics 2010;9:550-564.

15 Gong L, Zhou X, Wu Y, Zhang Y, Wang C, Zhou H, Guo F, Cui L: Proteomic analysis profile of engineered articular cartilage with chondrogenic differentiated adipose tissue-derived stem cells loaded polyglycolic acid mesh for weight-bearing area defect repair. Tissue Eng Part A 2014;20:575-587.

16 Wiese S, Reidegeld KA, Meyer HE, Warscheid B: Protein labeling by iTRAQ: a new tool for quantitative mass spectrometry in proteome research. Proteomics 2007;7:340-350.

17 Unwin RD: Quantification of proteins by iTRAQ. Methods Mol Biol 2010;658:205-215.

18 Horton ER, Byron A, Askari JA, Ng DH, Millon-Fremillon A, Robertson J, Koper EJ, Paul NR, Warwood S, Knight D, Humphries JD, Humphries MJ: Definition of a consensus integrin adhesome and its dynamics during adhesion complex assembly and disassembly. Nat Cell Biol 2015;17:1577-1587.

19 Ashburner M, Ball CA, Blake JA, Botstein D, Butler H, Cherry JM, Davis AP, Dolinski K, Dwight SS, Eppig JT, Harris MA, Hill DP, Issel-Tarver L, Kasarskis A, Lewis S, Matese JC, Richardson JE, Ringwald M, Rubin GM, Sherlock G: Gene ontology: tool for the unification of biology. The Gene Ontology Consortium. Nat Genet 2000;25:25-29.

20 Kanehisa M, Goto S, Sato Y, Furumichi M, Tanabe M: KEGG for integration and interpretation of large-scale molecular data sets. Nucleic Acids Res 2012;40:D109-114.

21 Zhang S, Weinheimer C, Courtois M, Kovacs A, Zhang CE, Cheng AM, Wang Y, Muslin AJ: The role of the Grb2-p38 MAPK signaling pathway in cardiac hypertrophy and fibrosis. J Clin Invest 2003;111:833-841.

-22 Wang B, Du T, Wang Y, Yang C, Zhang S, Cao X: Focal adhesion kinase signaling pathway is involved in mechanotransduction in MG-63 cells. Biochem Biophys Res Commun 2011;410:671-676.

-23 Hu Y, Bock G, Wick G, Xu Q: Activation of PDGF receptor alpha in vascular smooth muscle cells by mechanical stress. Faseb J 1998;12:1135-1142.

24 Lin CC, Melo FA, Ghosh R, Suen KM, Stagg LJ, Kirkpatrick J, Arold ST, Ahmed Z, Ladbury JE: Inhibition of basal FGF receptor signaling by dimeric Grb2. Cell 2012;149:1514-1524.

-25 Belov AA, Mohammadi M: Grb2, a double-edged sword of receptor tyrosine kinase signaling. Sci Signal 2012;5:49. 


\section{Cellular Physiology Cell Physiol Biochem 2017;44:1509-1525

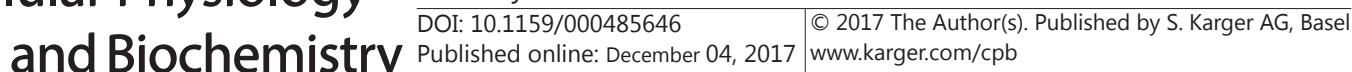

Xu et al.: Grb2 Mediate Mechanotranduction in Chondrocytes

26 Saito T, Nishida K, Furumatsu T, Yoshida A, Ozawa M, Ozaki T: Histone deacetylase inhibitors suppress mechanical stress-induced expression of RUNX-2 and ADAMTS- 5 through the inhibition of the MAPK signaling pathway in cultured human chondrocytes. Osteoarthritis Cartilage 2013;21:165-174.

27 De Croos JN, Jang B, Dhaliwal SS, Grynpas MD, Pilliar RM, Kandel RA: Membrane type-1 matrix metalloproteinase is induced following cyclic compression of in vitro grown bovine chondrocytes. Osteoarthritis Cartilage 2007;15:1301-1310.

28 Israeli-Rosenberg S, Chen C, Li R, Deussen DN, Niesman IR, Okada H, Patel HH, Roth DM, Ross RS: Caveolin modulates integrin function and mechanical activation in the cardiomyocyte. Faseb J 2015;29:374-384.

-29 Sanz-Ramos P, Mora G, Ripalda P, Vicente-Pascual M, Izal-Azcarate I: Identification of signalling pathways triggered by changes in the mechanical environment in rat chondrocytes. Osteoarthritis Cartilage 2012;20:931-939.

-30 Luo CW, Wu CC, Ch'ang HJ: Radiation sensitization of tumor cells induced by shear stress: the roles of integrins and FAK. Biochim Biophys Acta 2014;1843:2129-2137.

-31 Giubellino A, Burke TR, Jr., Bottaro DP: Grb2 signaling in cell motility and cancer. Expert Opin Ther Targets 2008;12:1021-1033.

-32 Li S, Kim M, Hu YL, Jalali S, Schlaepfer DD, Hunter T, Chien S, Shyy JY: Fluid shear stress activation of focal adhesion kinase. Linking to mitogen-activated protein kinases. J Biol Chem 1997;272:30455-30462.

-33 Tari AM, Lopez-Berestein G: GRB2: a pivotal protein in signal transduction. Semin Oncol 2001;28:142-147.

-34 Ravichandran KS: Signaling via Shc family adapter proteins. Oncogene 2001;20:6322-6330.

-35 Murase S: Impaired Focal Adhesion Kinase-Grb2 Interaction during Elevated Activity in Hippocampal Neurons. Int J Mol Sci 2015;16:15659-15669.

-36 Mohanty P, Bhatnagar S: Structural basis of focal adhesion targeting domain-mediated signaling in cardiac hypertrophy. J Recept Signal Transduct Res 2017;37:38-50.

-37 Nihal M, Wood GS: c-CBL regulates melanoma proliferation, migration, invasion and the FAK-SRC-GRB2 nexus. Oncotarget 2016;7:53869-53880.

-38 Cheng SY, Sun G, Schlaepfer DD, Pallen CJ: Grb2 promotes integrin-induced focal adhesion kinase (FAK) autophosphorylation and directs the phosphorylation of protein tyrosine phosphatase alpha by the SrcFAK kinase complex. Mol Cell Biol 2014;34:348-361.

-39 Levy-Apter E, Finkelshtein E, Vemulapalli V, Li SS, Bedford MT, Elson A: Adaptor protein GRB2 promotes Src tyrosine kinase activation and podosomal organization by protein-tyrosine phosphatase in osteoclasts. J Biol Chem 2014;289:36048-36058.

40 Liang W, Zhu C, Liu F, Cui W, Wang Q, Chen Z, Zhou Q, Xu S, Zhai C, Fan W: Integrin beta1 Gene Therapy Enhances in vitro Creation of Tissue-Engineered Cartilage Under Periodic Mechanical Stress. Cell Physiol Biochem 2015;37:1301-1314.

41 Vyner MC, Amsden BG: Polymer chain flexibility-induced differences in fetuin A adsorption and its implications on cell attachment and proliferation. Acta Biomater 2016;31:89-98.

42 Liu X, Zhang X, Lv Y, Xiang J, Shi J: Overexpression of syntenin enhances hepatoma cell proliferation and invasion: potential roles in human hepatoma. Oncol Rep 2014;32:2810-2816.

43 Dasgupta S, Menezes ME, Das SK, Emdad L, Janjic A, Bhatia S, Mukhopadhyay ND, Shao C, Sarkar D, Fisher PB: Novel role of MDA-9/syntenin in regulating urothelial cell proliferation by modulating EGFR signaling. Clin Cancer Res 2013;19:4621-4633.

\$4 Kegelman TP, Das SK, Hu B, Bacolod MD, Fuller CE, Menezes ME, Emdad L, Dasgupta S, Baldwin AS, Bruce JN, Dent P, Pellecchia M, Sarkar D, Fisher PB: MDA-9/syntenin is a key regulator of glioma pathogenesis. Neuro Oncol 2014;16:50-61.

45 Seguin CA, Bernier SM: TNFalpha suppresses link protein and type II collagen expression in chondrocytes: Role of MEK1/2 and NF-kappaB signaling pathways. J Cell Physiol 2003;197:356-369.

46 Wisniewski JR, Zougman A, Nagaraj N, Mann M: Universal sample preparation method for proteome analysis. Nat Methods 2009;6:359-362.

47 Sandberg A, Lindell G, Kallstrom BN, Branca RM, Danielsson KG, Dahlberg M, Larson B, Forshed J, Lehtio J: Tumor proteomics by multivariate analysis on individual pathway data for characterization of vulvar cancer phenotypes. Mol Cell Proteomics 2012;11:M112.016998.

48 Wang P, Cao X, Nagel DJ, Yin G: Activation of ASK1 during reperfusion of ischemic spinal cord. Neurosci Lett 2007;415:248-252. 